\title{
Konaklama İşletmelerinde Rekabet Avantajı Kaynakları: Bodırum Örneği
}

\section{Dr. Öğr. Üyesi Yıldırım Yıldırım ${ }^{1}$ Bilim Uzmanı Hakan Çakırli ${ }^{2 *}$}

Geliş tarihi: 10.01 .2020

Kabul tarihi: 21.02.2020

\section{Atıf bilgisi: \\ IBAD Sosyal Bilimler Dergisi \\ Sayı: 7 Sayfa: 207-221 \\ Yıl: 2020 Dönem: Yaz}

This article was checked by iThenticate. Similarity Index $10 \%$

Bu makalede araştırma ve yayın etiğine uyulmuștur.

1 Düzce Üniversitesi Akçakoca Turizm İsletmeciliği ve Otelcilik Yüksekokulu, Türkiye, vildirimyildirim@duzce.du.tr ORCID ID 0000-0002-5851-7788

2 Düzce Üniversitesi Akçakoca Turizm İșletmeciliği ve Otelcilik Yüksekokulu, Türkiye, hakancakirli@hotmail.com ORCID ID 0000-0001-6484-1181

\section{ÖZ}

$\mathrm{Bu}$ çalışmada temel olarak konaklama işletmelerinin rekabet avantajı kaynakları ele alınmaktadır. $\mathrm{Bu}$ doğrultuda araştırmacının temel amacı konaklama işletmelerinin rekabet etmede avantaj sağladığı kaynakları belirlemektir. Bu çalışma için örnek olarak Bodrum/Muğla destinasyonu seçilmiştir. Araştırmanın amacı kapsamında nitel verilerin yarı yapılandırılmış görüșme tekniği ile toplandığı bu çalıșmada Bodrum'da faaliyet gösteren 36 adet 5 yıldızlı konaklama işletmelerinden gönüllülük esasına dayalı olarak mülakat yapmayı kabul eden 16 konaklama işletmesi seçilerek, yöneticileri ile yüz yüze görüşme yöntemiyle veriler toplanmıştır. Elde edilen verilerin işlenmesinde içerik analizi tekniği kullanılmıştır. Araştırmanın bulguları doğrultusunda konaklama işletmeleri arasında yoğun bir rekabetin yaşandığı, işletmelerin birbirleri ile yarışırken hizmet kalitelerini arttırmaya özen göstererek sadık müsțeri kitlelerini olușturmaya çalıștıkları sonucuna varılmıştır. Ayrıca çalışmanın sonuçlarında işletmelerin kaliteli hizmet vermek adına işletme bünyesinde çalışan personele, fiyat-kalite dengesini sağlamaya, tedarikçileri ile iyi ikili ilişkiler kurmaya, müşteri geri bildirimlerini dikkatli şekilde takip etmeye özen gösterdikleri görülmüştür.

Anahtar Kelimeler: Otel işletmeleri, Rekabet avantaj1, Rekabet stratejileri, Porter'ın beş güç modeli, Bodrum 


\title{
Competitive Advantage Sources in Accomodation: Case of Bodrum
}

\author{
Assist. Prof. Dr. Yıldırım Yıldırım \\ Hakan Çakırlı ${ }^{*}$
}

First received: 10.01 .2020

Accepted: 21.02.2020

\section{Citation:}

IBAD Journal of Social Sciences

Issue: $7 \quad$ Pages: 207-221

Year: 2020 Session: Summer

This article was checked by iThenticate. Similarity Index 10\%

1 Duzce University, Department of Tourism and Hospitality Management, Turkey, vildirimyildirim@duzce.edu.tr ORCID ID 0000-0002-5851-7788

2 Duzce University, Department of Tourism and Hospitality Management, Turkey, hakancakirli@hotmail.com ORCID ID 0000-0001-6484-1181

\footnotetext{
* Corresponding Author
}

\begin{abstract}
In this study, the sources of competitive advantage of accommodation establishments are mainly discussed. In this respect, the main purpose of the researcher is to determine the sources in which the hospitality businesses provide an advantage in competition. Bodrum / Muğla destination was chosen as the sample for this study. Qualitative data were collected by semi-structured interview technique. 16 accommodation establishments were selected randomly from 5 star accommodation establishments operating in Bodrum. Data were collected by interviewing the managers of these 16 accommodation establishments. Content analysis technique was used to process the obtained data. In line with the findings of the research, it was concluded that there was intense competition among accommodation establishments and that the enterprises tried to create loyal customer masses by taking care to increase the service quality while competing with each other. In addition, in the results of the study, it is seen that the companies take care to provide price-quality balance, establish good bilateral relations with their suppliers and follow customer feedback carefully to provide quality service to the personnel working in the enterprise.
\end{abstract}

Keywords: Hotel businesses, Competitive advantage, Competitive strategies, Porter's Five Force Model, Bodrum 


\section{GİRIŞ}

Küreselleşme ile beraber uluslararası ticaret ilişkilerinin hızlanması, ülkeler arasındaki sınırların kalkması, iletişim ve ulaşım teknolojilerinin tüm dünyanın kullanımına sunulması gibi ekonomik, sosyal, teknolojik alanlarda yaşanan değişimler firmaların sürekli olarak kendilerini değerlendirmeleri gereksinimini ortaya çıkarmıştır.

Firmaların günümüzdeki hedeflerine bakıldığında; sürekli bir biçimde gelişen ve değişen dünyayı takip etmek, devamlı büyümekte olan pazarlardan daha fazla pay alabilmek, tehlikeleri firsata çevirmek olduğu görülmektedir. Bu doğrultuda hareket eden firmalar rekabet açısından önemli avantajlara sahip olabileceklerdir. Fakat bunu devamlı hale getirmek için büyük oranda çaba sarf etmeleri gerekmektedir. Firmaların rekabetçiliğini sürdürülebilir hale getirmelerinin yolu ise, onların firma ve sektör bazında uygun stratejiler geliştirmelerini ve bu bağlamda yoğun olarak çaba sarf etmelerini gerekli kılmaktadır. Tıpkı savaşlarda olduğu şekliyle bu alanda da kazanım elde etmenin yolu doğru stratejiler geliştirmekten geçmektedir. Gerek yerel ve gerekse de küresel anlamda kalkınmak ve büyümek, firmaların uyguladığ1 rekabet stratejilerine ve bu stratejilerin etkinliğine bağlı olmaktadır.

Konaklama işletmelerinin yer aldığı piyasalarda rekabetçi olarak kalabilmek, firmalar açısından zordur. Firmalar rekabet açısından avantaj yakalamak için müşterileri iyi analiz etmeli ve onların her geçen gün daha da karmaşıklaşan isteklerine cevap verebilmelidirler. Çünkü günümüzde müşteriler, kendilerini büyük bir gruba ait üyeler şeklinde görmekte ve kendilerine de buna uygun bir biçimde davranılmasını talep etmektedirler. Günümüzde bunun bilincinde olarak müşterilerini tanıyan, onun isteklerine cevap verebilen işletmeler başarılı olmaktadır.

Hızla değişen ve gelişen pazarlarda otel işletmelerinin sundukları hizmetler, yararlandıkları üretim teknolojileri hızla değişmektedir. Endüstri işletmeleri için olduğu gibi hizmet işletmelerinde de rekabet avantajı sağlayan yetenekler, bir zaman sonra yaşanan hızlı değişimler nedeniyle bu özelliklerini kaybetmektedir. Rekabet avantajını korumanın zor olduğu bu tür pazarlarda, pazara ilk giren veya pazara yeni bir hizmet sunan otel işletmesi kısa sürede rekabet üstünlüğünü kaybedebilmektedir. Rekabet avantajının sürekli hale getirilmesi zor olmakta ve bu nedenle kısa dönemli geçici rekabet avantajları için stratejik hamleler yapmak gerekmektedir.

Hizmet sektöründe ayırt edici bir özellik ortaya koymak ve hizmet açısından farklılaşmak oldukça zor olabilmektedir. Çünkü hizmetlerin soyut olma, elle tutulamama, standartlaştırılamama, yasal olarak patent alma ve know-how bilgisini koruma süreçlerinin zor hatta imkansız olması konaklama işletmelerindeki rekabet düzeyinin çoğu zaman endüstriyel ürün ve markalardan daha zor olabildiği görülmektedir (Eser, 2007). Bu yüzden otel işletmelerinin rekabette ayırt edici olabilmeleri için niş alanlar bulması, müşteri merkezli bir yapı sergilemesi ve değişen pazar yapısını yakından takip etmesi gerekmektedir. Kısaca hizmet sektöründe faaliyet gösteren işletmeler kaynakları ve hedefleri ile tutarl1, sağlam, rekabetçi temellere oturan güvenli yollar bulmaları gerekmektedir (İslamoğlu ve diğ., 2006, s. 95).

Değişimin yavaş olduğu pazarlarda faaliyet gösteren otel işletmelerinin sunduğu ürünler, rekabet avantaj1 sağlayan temel yetenekleri ve faaliyetleri korunduğu için rekabet üstünlüğünün sürdürülmesi kolaydır. Bu özelliklerdeki pazarlarda güçlü know-how, patent, markaların bulunduğu ve müşteri bağımlılığı çok etkili olduğu için rekabet avantajı devam ettirilir. Standart pazarlarda otel işletmelerinin rekabet avantaj1 daha çok ölçek ekonomilerinde üretim gerçekleştirmeleri halinde sürdürülür. Ayrıca yeni yatırımlarda ve taklit edilmesi çok pahalı olan yeteneklerin geliştirilmesi ile de rekabet avantajı korunabilir. Otel işletmelerinin kongre merkezleri, golf sahaları vb. alanlara yaptıkları yatırımlar, rekabet avantajının devamı ve gelişen pazarlardan daha fazla pay alabilmek için yapmış oldukları yatırımlardır. Otel işletmeleri arasında yaşanan rekabetin şiddeti, faaliyet gösterdiği pazarda yer alan işletmeler tarafindan temel yeteneklerin ve avantajların durumuna bağlı olarak değişir.

Bugün olduğu gibi gelecekte de tüm ülke ekonomileri için yarattığı çıktılar bakımından turizm sektörünün en çok dikkat çeken sektörlerden biri olma konumunu sürdürmesi beklenmektedir. Turizm sektörünün pek çok sektörle olan yakın işbirliği, emek yoğun bir sektör olmasına karşın modern teknolojiye olan bağımlılığı, bire-bir müşteri odaklı olması ve müşteri memnuniyeti ağılıklı çalışması ve belki de en önemlisi üretilen ürünün müssterinin ayağına götürülme şansının olmaması bu sektörü hem 
diğer hizmet sektörlerinden hem de tüm sanayi ve tarım sektörlerinden farklı kılmaktadır. Fakat bu farklı1ık bu sektörün gözden çıkarılmasını değil, daha çok üzerine gidilmesini gerektirmektedir. Bu bağlamda büyüyen ve değişen turizm pazarından arzulanan payın elde edilmesi, ulusal ve uluslararası pazarlarda rekabet üstünlüğünün sürdürülebilirliği için, karşılaştırmalı üstünlüklerin rekabetçi üstünlüklere dönüş̧ürülmesi şarttır. Bu nedenledir ki turizm sektörü; doğal çevrenin korunmasının yanı sıra, alanında iyi eğitim almış nitelikli işgücü ile kaliteli hizmet sunarak, piyasadaki gelişmeleri iyi analiz edip yeni ürünler geliştirerek, turistik talebin gereksinimlerini iyi tahlil ederek ve bu doğrultuda AR-GE faaliyetlerini sürdürüp yenilikleri uygulamaya koyarak doğru ve yeniliklere açık bir turizm politikasıyla rekabet gücünü artırmak zorundadır.

Büyük bir turizm pazarına sahip olan Türkiye'de turizm sektöründe birçok işletmenin faaliyet göstermesinin yanında birçok yeni işletme sektöre giriş yapmaktadır. Bunun doğal getirisi olarak işletmeler arasındaki rekabet yarışı gün geçtikçe daha da zorlu hale gelmektedir. Bu rekabet içerisinde birçok işletme pazarda tutunamayarak küçülmekte hatta pazardan çekilmektedir. Diğer yandan bazı işletmeler de rakiplerinden öne çıkarak pazar paylarını arttırarak daha çok kazanç elde etmekte ve büyümektedir.

$\mathrm{Bu}$ araştırmanın amacı Bodrum ilçesinde yer alan konaklama işletmelerinin rekabet içerisinde kullandıkları kaynakların belirlenmesi ve bu kaynakların hangilerinin rekabet avantajı elde etmede daha etkili olduğunun tespit edilmesidir. Bodrum ilçesi işletmeler açısından rekabetin en üst seviyede olduğu pazarlardan birisidir. $\mathrm{Bu}$ açıdan bu bölgede yer alan konaklama işletmelerinin rekabette öne çıkabilmek adına kullandıkları kaynakların belirlenmesi işletmeler arasındaki rekabet avantajı kaynaklarının tespiti için önem arz etmektedir.

\section{KONAKLAMA İŞLETMELERI}

İnsanlar tarihin çok eski dönemlerinden bugüne ticaret yapmak, kutsal yerleri ziyaret etmek, sağlık gibi nedenlerden dolayı çeşitli seyahatler gerçekleştirmişlerdir. İlk zamanlarda, ticaret, dinsel ve sağlı amaçlı gerçekleştirilen seyahat faaliyetlerine, zaman içerisinde merak, yeni yerleri görme arzusu, macera, eğlence ve spor gibi amaçların da girmesi, bu faaliyetlerin gerçekleştirilmesi sırasında konaklama ihtiyacını doğurmuştur (Özel, 2012). Bununla birlikte, insanların temel ihtiyaçları arasında yer alan konaklama, yiyecek-içecek gibi ihtiyaçların karşılanma gereksinimi, yer değiştirme faaliyetlerinin ilk evrelerinden başlayarak otel işletmelerinin dünyadaki ilk örnekleri olan han ve kervansarayların ortaya çıkmasını sağlamıştır (Erdem, 2002). Öte yandan, insanların gerek başka yerlere seyahat etme durumlarının gelişerek süreklilik göstermesi, gerekse endüstri devrimi ile birlikte ekonomik ve sosyal statülerindeki gelişmeler, yaşam standartlarına yansımışıı. Bu durum ise insanların satın alma ve tüketim kararlarının tüm sektörlerde radikal bir şekilde farklılaşmasına neden olmuştur (Özel, 2012; Özdemir ve Kervankıran, 2011). İnsan yaşamında meydana gelen bu değişim ve gelişmeler özellikle konaklama işletmesi içerisinde yer alan günümüz modern otel işletmelerinin ortaya çıkmasını sağlamıştır.

Türkiye'de modern anlamda açılan ilk otel 1892 yılında Wagon-Lits tarafindan İstanbul'da faaliyete geçirilen Pera Palas Otel'i olmuştur. Bu otel 120 oda ve 200 yatak kapasitesiyle hizmete sunulmuştur. Pera Palas Oteli'ni, 1914 yılında Avrupa'nın ve Ortadoğu'nun o dönem için en lüks oteli olarak nitelendirilen Tokatliyan Oteli takip etmiştir (Akgöz, 2013, s. 10).

1923 y1lında Cumhuriyet'in ilanı ile temelleri atılan Türkiye Cumhuriyeti'nde her alanda olduğu gibi otelcilik sektöründe de yeni bir yapılanmaya girilmiştir. 1931 yılında uzun yıllar Türk turizmine hizmet verecek olan Park Otel İstanbul'da insanların hizmetine sunulmuştur. Bu yıllarda sayıları artan otel işletmeleri, Otelciler ve Hancılar Cemiyeti'nin kurulmasına öncülük etmiştir (Çavuş ve Öncüer, 2009). 1950 yılında Türk Hükümeti ile Hilton şirketi arasında yapılan anlaşmaya bağlı olarak 1955 yılında " 29. Hilton Oteli” İstanbul'da hizmete açılmışıır. Öte yandan 1956 yılında tamamen yerli sermaye ile kurulan ilk modern işletmelerden biri olan Divan Oteli Türkiye'nin turizm tarihinde önemli yeri olan işletmelerden birisini oluşturmaktadır (Roney, 2011).

Araştırma konusu dâhilinde bahsedilen diğer konaklama tesislerinin tanımları şu şekildedir: 
Pansiyon: Turizm Tesisleri Yönetmeliği'ne göre pansiyonlar, konaklama tesisi olarak planlanıp inşa edilen, yönetimi basit, müşterilerin kendi yemeklerini bizzat hazırlayabilme imkânı bulunan, en az 5 odal1 tesislerdir (Resmi Gazete, 2000).

Apart Otel: Mesken olarak kullanılmaya elverişli bağımsız apartman ya da villa tipinde inşa ve tefriş edilen, müşterinin kendi yeme ve içme ihtiyaçlarını karşılayabilmesi için gerekli teçhizat ile donatılan ve otel olarak işletilen konaklama tesisleridir. Apart oteller, belgeli bir otel veya tatil köyü veya turizm kompleksi yatırım ve/veya işletmesi bütünü içinde yer alır (Resmi Gazete, 2000).

Tatil Köyü: Ülkemiz turizm tesisleri yönetmeliğince tatil köyleri, doğal güzellikler içerisinde, rahat bir konaklama yanında çeşitli spor, eğlence ve satış hizmetlerinin de sağlandığı yaygın yerleşim düzenindeki en fazla iki katlı yapılardan oluşan, en az 60 odalı konaklama tesisleri olarak tanımlanmaktadır (Resmi Gazete, 2000).

\section{REKABET KAVRAMI}

Rekabet kavramı birçok disiplin tarafından tanımı yapılmış ve zaman içerisinde de değişik anlamlarda kullanılmıştır. Genel manada ise rekabet; belli bir çıkar sağlayabilmek amacıyla diğerlerini geçmeye çalışmak ya da aynı pozisyonda olan kişilere karşı birtakım yararlar sağlamaya dönük olarak üstünlük sağlamak amacıyla yarışmak manasına gelmektedir (Topçuoğlu, 2001). Bir diğer tanıma göre ise rekabet; bir yarışta yer alan rakiplerin davranışlarına benzetilmekte, yarışın sebebinin ise mal kaynaklarının sınırlı olmasından kaynaklandığı ileri sürülmektedir (Hatiboğlu, 1995).

Rekabet, doğanın ve yaradılışın bir fitratıdır. Genel itibariyle rekabet; bir ödülü kazanmak yahut kısıtlı olan bir şeyi paylaşmak amacıyla önceden belirlenmiş̧ belli kurallar ya da sınırlamalar dâhilinde birden fazla aktör arasında yarışma durumudur. Rekabetin sosyal ve siyasal boyutları da bulunmaktadır. Rekabet durumunda temel insan hakları ve özgürlükleri çiğnenemez, ayrımcılık gibi bir durum söz konusu olamaz (Kavrakoğlu, 2002). Rekabet, yalnızca benzer işi yapan mevcut işletmeler arasında olmamaktadır. Pazara girebilecek potansiyel rakipleri de hesaba katmak gerekmektedir. Bir pazardaki rekabetin kuvvetini rakiplerin miktarı kadar onların satış düzeyi ve kuvvetinin aynı olma olasıllı̆ı etmeni de etkilemektedir (Hatipoğlu, 1995).

2. Dünya Savaş’ından sonra, dünya üzerinde etkileri son derece ağır ve yıkıcı olan bir ekonomik kriz yaşanmıştır. Üretimin oldukça düşük, fakat talebin ise çok fazla olmasından dolayı aşırı bir enflasyon durumu ile karşı karşıya kalınmıştır. Bu gelişmeler yeni bir dünya düzenini de beraberinde getirmeye başlamıştır. Bu doğrultuda ekonomiye yön vermek için Amerika Birleşik Devletleri'nin önderliği ile Dünya Bankası ile IMF kurulmuştur. Komünizmin Avrupa'da yayılmasını önlemek amacıyla Amerika Birleşik Devletleri tarafından ülkelere Marshall yardımları yapılmışır (Karluk, 1996). Daha sonra Avrupalı devletlerce kurulan Avrupa Birliği ile sinırlar ortadan kalkarak uluslararası rekabetin yoğunluğu artmıştır.

1960'lı y1llarda bu yoğun rekabet ortamı firmaları ciddi bir stratejik yarış içerisine sokmuştur. Bu manada firmalar çeşitli araştırmalar yapmıştır. Rekabet dönemlerine bakıldığında, 1960'll yıllarda rekabet üstünlüğü üretime, 1970'li yıllarda maliyete, 1980'li yıllarda ise kalite ve hıza dayalıydı. 1990 ve 2000'li yıllarda ise farklılaşma esasına dayalı olarak rakiplerden daha farklı ve üstün özelliklere sahip, daha kaliteli ürünler üretmeye dayalı olmuştur (Mohelska ve Sokolova, 2018). 2000'li yıllarda rekabette kalıcılık ile devaml11ık, sadece rakipten daha iyi yapmaya yetmeyecek hale gelmiştir. Önemli olan, rakipten daha farklı yapabilmektir (Kırım, 1998). Bunun için işletmeler hedef müşterilerine nasıl ulaşabilecekleri ve mal ve hizmetlerini nasıl ulaştırabilecekleriyle ilgili olarak müşterilerini alt bölümlere ayırabilecekleri ve onlarla kalıcı ilişkiler kurabilecekleri Müşteri İlişkileri Yönetimini (Customer Relationship Management-CRM) kullanmaya başlamışlardır (Porter, 2000).

İktisadi açıdan baktığımızda ise rekabet, bu bilimin temelini oluşturan unsurlardan biridir. İlk olarak Adam Smith, bu kavramın öneminin bilincinde olarak bilimsel bir şekilde iktisadın tanımını yapmıştır. Adam Smith, rekabeti piyasa sisteminin merkezi ögesi olarak değerlendirmenin yanı sira, bu kavramın en iyi düzenleyici el ve işletmeler arası savaş şeklinde yorumlamıştır. Smith'in yapmış olduğu bu değerlendirme kazan-kaybet anlayışının hâkim olmasına zemin oluşturmuştur. Bu doğrultuda bir mücadelede başarı sağlamak isteniyorsa, bir başkası kaybetmelidir (Aktan ve Vural, 2004). Bu sebepten 
ötürü Smith'in belirttiği rekabet, piyasada yer alan değişkenlere uyum gösterirken, firmaların kâr elde etmeleri, rakiplerinin işlerini zora sokma şeklinde kabul görmektedir.

Klasiklere göre rekabet, dinamik değil, aksine piyasa sürecine ilişkin bir kavramdır. Yani rekabet dengeye ulaşabilmek için kullanılan bir araçtır. Neo Klasikler bu çerçevede tam rekabet kavramını geliştirmişlerdir. Tam rekabet; piyasada birçok sayıda alıcı ile satıcının mevcut olduğu, giriş ve çıkışların serbest olduğu, tam anlamıyla bir bilgi akışının olduğu, türdeş ve bölünebilir malların yer aldığı piyasalardır (Özkan, 2007). Bu şekilde de Klasiklerin dinamik bir süreç şeklinde dengeye gelmeyi sağlayan rekabeti, neo-klasikler de dengenin nerede gerçekleşmesi gerektiğini belirten ve dengeden uzaklaşılmasını engelleyen statik durumlar şeklinde ele almışlardır (Aktan ve Vural, 2004). Buradan da anlaşılacağı üzere bu kavram her dönemde farklı çevreler tarafından farklı bir şekilde yorumlanmıştır.

Rekabetin Korunması Hakkında Kanun'un (www.rekabet.gov.tr) 3. maddesinde rekabet; "mal ve hizmet piyasalarındaki teşebbüsler arasında özgürce ekonomik kararlar verilebilmesini sağlayan yarış" şeklindedir. Bu doğrultuda piyasada yer alan dağıtıcılar ve bunların bünyesindeki bayiliklerin iradelerini ortaya koyarak ekonomik kararlar alabilmeleri yarışma şartlarının herkes için aynı olduğu teşvikmotivasyonunun vazgeçilmez olduğunun benimsenmesi gücüdür. Bir şirket için rekabetçi açıdan daha güçlü hale gelebilmenin anahtarı, "ben daha iyiyim" felsefesini tüm çalışanlarına benimsetmesi, bu doğrultuda somut adımlar ve stratejiler oluşturmasından geçmektedir (Hatiboğlu, 1995). Rekabette ana hedef; en iyi ölçütü yakalayabilme veya yerine getirebilmedir.

TDK' ya göre rekabet, "aynı amacı güden kişiler arasındaki çekişme, yarışma, yarış” olarak tanımlanmaktadır. Kuruluşların kapsamındaki ekonomik anlamı ise bir tanıma göre, birden fazla rakibin yer aldığı, ancak ne üreticilerin ne de tüketicilerin birlikte fiyatı saptayamadıkları, giriş ve çıkışın özgür, bilgi erişiminin ve akışının tam, ürünün ise bağdaşık olduğu, kısaca fiyatın veri olarak bulunduğu bir durum olmaktadır (Dinçer, 1998). Bu tanımlardan da anlaşılacağı gibi firmalar yaşamlarını sürdürebilmek için rekabet etme durumundadırlar. Kuruluşlar değişen rekabet ortamlarına uyabilmek için bazı rekabet stratejileri oluşturmak zorunda kalmışlardır. Firmaların rekabet stratejileri küreselleşme etkileriyle günümüze kadar değişimlerini ve gelişmelerini sürdürmüşlerdir.

\section{PORTER: BEŞ GÜÇ MODELI}

Porter'ın Beş Güç modeli şunları içerir 'yatay' rekabetten üç kuvvet: ikame ürünlerin veya hizmetlerin tehdidi ve yeni girenlerin tehdidi ve 'dikey' rekabetten iki güç: tedarikçilerin pazarlık gücü ve alıcıların pazarlık gücüdür.

Şekil 1. Porter: Beş Güç Modeli

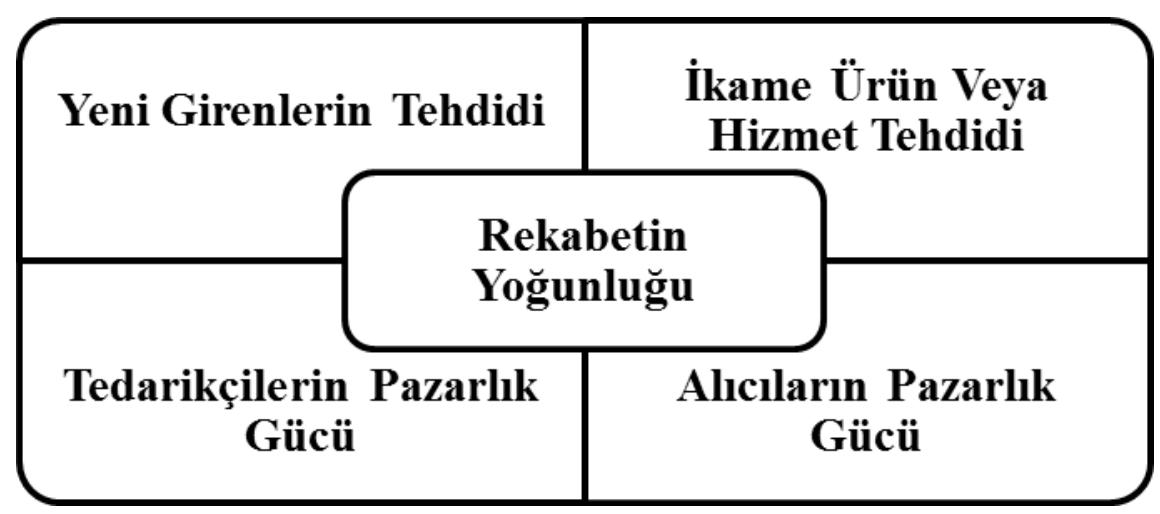

\section{Yeni Girenlerin Tehdidi}

Yüksek getiri sağlayan kârlı pazarlar yeni firmaları çekmektedir. Bu durum sektördeki tüm firmalar için kârlılığı azaltacak olan birçok yeni katılımcı ile sonuçlanmaktadır. En çekici bölüm, giriş engellerinin yüksek ve çıkış engellerinin düşük olduğu bölümdür. Birkaç yeni firma girebilir ve performans göstermeyen firmalar kolaylıkla çıkabilir (Porter, 2010). 


\section{İkame Ürün veya Hizmet Tehdidi}

Bir sektörde faaliyet gösteren bütün işletmeler, ikame ürünler üreten işletmeler ile birbirleriyle rekabet halindedirler (Porter, 2010: 28). Üretilen ikame ürün ya da hizmetler, firmaların belirlemiş oldukları fiyatlara bir sınır çizerek kârı düşürür. Bu durumun oluşmasının önüne geçmek için işletmelerin ya ürün farklılaştırması ya da ürünün niteliğini artırması gerekmektedir. Sanayide üretilen ve fiyat-performans ilişkisinin daha iyi hale getirilmesini sağlayanlar en fazla ilgi çeken ürünlerdir. Birtakım sebeplerden ötürü rekabet yükseldiğinde ve performansın yükseltilmesi ya da fiyatın azaltılması durumunda ikame ürünler hızla rekabetin içerisine girerler (Pearce II ve Robinson, 2015, s. 98). Eğer ikame ürünlerin saptanması isteniyorsa, sektörde yer alan ürünle aynı amaca dönük olan ürünlerin araştırılması gerekmektedir. Bu araştırmalara sektör dışı kalmış işler de ilave edilebilir (Porter, 2010, s. 29).

\section{Tedarikçilerin Pazarlık Gücü}

Girdi piyasası, tedarikçilerin pazarlık gücü şeklinde tanımlanmaktadır. Eğer az sayıda ikame mevcutsa hammadde, parça, işçilik gibi tedarikçileri işletme için bir güç kaynağı olabilmektedir. Eğer bir bisküvi üreticisi iseniz ve piyasada tek bir un satıcısı varsa, bu durumda sadece o satıcıdan alışveriş yapmak zorunda olursunuz. Tedarikçiler burada firma ile çalışmak istemeyebilir ya da orijinal kaynaklar için oldukça yüksek fiyatlar isteyebilir (Eren, 2013).

Bir tedarikçinin güçlü olduğu koşullar aşağıdaki gibidir (Porter, 2010, s. 44-45):

- Tedarikçi değişimine göre tedarikçi değişim maliyetleri

- Girdilerin farklılaşma derecesi

- Girdilerin maliyete veya farklılaşmaya etkisi

- İkame girdilerin varlığı

- Dağıtım kanalının gücü

- Tedarikçi yoğunluğunun firma yoğunluğuna oranı

- Çalışan dayanışması (örneğin sendikalar)

- Tedarikçi rekabeti: dikey olarak ilerleyebilme alıcıyı entegre etmek ve kesmek

\section{Alıcıların Pazarlık Gücü}

Çıktı piyasası, müşterilerin pazarlık gücü şeklinde tanımlanmaktadır. Müşteriler işletmeyi baskı altına almakta ne kadar etkiliyse, müșterinin fiyat değişikliğine olan duyarlılığı da o derece etkilidir. Firmalar sadakat programı uygulayarak alıcının gücünü düşürmek isteyebilir (Özkan, 2007). Çünkü eğer alıcının çok sayıda alternatifi mevcutsa, alıcının gücü de o denli yüksektir. Örneğin, bağımsız olarak hareket ederlerse, alıcı gücü düşüktür. Eğer çok sayıda müşteri birlikte hareket eder ve fiyatların düşük olmasını isterse, şirketin çok sayıda müşteri baskısı nedeniyle başka seçeneği kalmayacaktır (Porter, 2010, s. 30).

Aşağıdaki şartlar oluşursa alıcılar güçlü olabilirler (Porter, 2010, s. 30-32):

- Alıc1 yoğunlaşma firma yoğunlaşma oranı

- Mevcut dağıtım kanallarına bağımlılık derecesi

- Pazarlık kaldıracı, özellikle sektörlerde yüksek sabit maliyetler

- Firma anahtarlama maliyetlerine göre alıcı değiştirme maliyetleri

- Alıcı bilgi kullanılabilirliği

- Fiyatları düşürmek

- Mevcut yedek ürünlerin mevcudiyeti

- Alıcı fiyat duyarlılı̆̆ 
- Endüstri ürünlerinin farksal avantaji (benzersizliği)

- Müşteri Değeri (RFM) Analizi

- Toplam işlem miktarı

\section{Rekabetin Yoğunluğu}

Çoğu sektörde rekabet yoğunluğu endüstrinin rekabet edebilirliğinin temel belirleyicisidir. İşletmelerin birbirleriyle olan rekabeti genel itibariyle fiyat indirimi, yeni ürünlerin pazara çıkarılması ve müşteri hizmetlerinin yükselmesi şeklinde olmaktadır. Birden çok rakibin baskı oluşturması veya yerlerini geliştirme imkânlarını fark etmeleri sonucu rekabet meydana gelmektedir (Porter, 2010, s. 21). Eğer rekabet oldukça yoğun bir şekilde yaşanıyorsa, bu durum sektör kârlılığını düşürür. Yoğun rekabet, birbiri üzerinde etkili olan birtakım ögeler neticesinde ortaya çıkmaktadır. Bu öğeler aşağıdaki gibidir (Porter, 2010, s. 22-25):

- Sayı bakımından oldukça fazla ve birbirine denk olan rakipler,

- Sektörel gelişimin ağır olması

- Sabit maliyetlerin ve depolama maliyetlerinin fazla olmas1,

- Geçiş maliyeti ile farklılaştırmanın mevcut olmaması,

- Kapasitenin yüksek oranlarda artmas1,

- Rakiplerin değişkenlik göstermesi,

- Yüksek çıkış engelleri

\section{YÖNTEM}

$\mathrm{Bu}$ araştırmada nitel araştırma yöntemi kullanılmıştır. Araştırma verileri, nitel araştırma yöntemleri içerisinde en sik kullanılan teknik olan görüşme tekniği kullanılarak elde edilmiştir. Araştırma tümevarım yaklaşımı temel alınarak yürütülmüş ve veriler bu yaklaşıma uygun olarak toplanmıştır.

Nitel bir araştırma, genellikle çeşitli koşullar altında meydana gelen olayları incelemek ve bir şeyin meydana gelmesine neden olan belirli bir olaya dikkat çekmek amaciyla yapılır. Nitel araştırmalarda konuların kapsamı sınırsızdır (Lindof ve Taylor, 2011). Araştırmada niteliksel bir yaklaşımın kullanılması, bir pazarlama araştırmacısının, müşterilerin veya işletmelerin küçük bir görüş örneğini ölçmesine ve motivasyonlarını, duygularını, müşterilerin satın alma davranışlarını iyice incelemesine yardımcı olur (Valenti ve Riviere, 2008). Tüm bu nedenlerden dolayı, nitel bir araştırmanın bu çalışmanın problemine daha uygun olduğuna karar verilmiştir.

Nitel araştırmanın temelleri; doğal çevreye duyarlılık, araştırmacının katılımcı rolü, bütünsel yaklaşım, algıların ortaya çıkarılması, araştırma tasarımında esneklik ve nitel verilerdir (Patton, 1990). Ayrıca, nicel araştırma yüzeysel ama genelleştirilebilir sonuçlar verirken, nitel araştırma daha derin ve açıklayıcı bir anlayış getirmektedir (Yıldırım ve Şimşek, 2011, s. 55). Nitel araştırmada veri toplama, veri analizi ve teori oluşturma süreçleri nicel araştırmalardan daha tutarlı ve birbiriyle ilişkilidir (Glaser ve Strauss, 1967).

Araştırmanın amacı turizm sektöründe hizmet veren konaklama işletmelerinin rekabet içinde kullandıkları avantajların kaynaklarını araştırmaktır. Çalışma nitel bir araştırma olarak yürütülmüş ve yarı yapılandırılmış görüşme tekniği kullanılmıştır. Yarı yapılandırılmış görüşme yöntemi esnek ve etkileşimlidir, ayrıca tekrar edilmesi mümkün olmayan sosyal bir süreçtir. Katılımcı ve görüşmeci yarı yapılandırılmış görüşme yönteminin ana unsurlarıdır. Yarı yapılandırılmış araştırmalarda kullanılan veriler, araştırmacı ve araştırılan arasında gelişen sosyal etkileşim sonucu meydana çıkar ve somutlukla ilgisi yoktur. Sonuç olarak da bu etkileşim, araştırmanın sonuçlarını etkiler ve yazım aşamasında dahi etkili olur. Yarı yapılandırılmış görüşme yöntemi nitel araştırma yöntemlerine girmektedir. Nitel araştırma yöntemleri, gözlem, görüşme ve doküman analizi gibi nitel araştırma yöntemleri kullanıldığ1 ve algılar, olaylar doğal ortamda gerçekçi ve bütüncül olarak konduğu bir araştırma yöntemidir (Aslan, 2008, s. 75-76). 
Yapılan literatür incelemesinden sonra konuya uygun sorular hazırlanmış ve turizm alanında uzman üç akademisyenin onayına sunulmuştur. Uzman görüşleri doğrultusunda sorular son şeklini almıştır. Görüşme formu 10 adet açık uçlu sorudan oluşturulmuştur. Görüşme soruları Porter'ın Beş Güç Modeli doğrultusunda konaklama işletmelerinin rekabet avantajı kaynaklarını belirleyecek şekilde hazırlanmıştır. Muğla İl Kültür ve Turizm Bakanlı̆̆g'ndan alınan bilgiye göre 2018 yılında Bodrum'da "Tatil Köyü" kapsamına giren 13 tane, 5 yıldızlı otel olarak hizmet veren 30 tane işletme faaliyet göstermektedir. Tatil köyü kapsamında faaliyet gösteren otellerden 2 tanesi 4 yıldızlı olduğu için evrenden çıkarılmıştır. 5 yıldızlı olan toplam 41 tesisten 5 tanesinin araştırma yapıldığı sırada faaliyette olmadığı öğrenilmiştir. Faaliyette olan 5 yıldızlı 36 otel işletmesi bu araştırmanın evrenini oluşturmaktadır. $\mathrm{Bu}$ işletmelerden 16 tanesi gönüllülük esasına dayalı olarak mülakat yapmayı kabul etmiş ve araştırmanın örneklemi oluşturulmuştur. Seçilen örneklem büyüklüğü anakütlenin \%44'ünü temsil etmektedir. Nitel araştırmalarda örneklem büyüklüğü: araştırmacının ne bilmek istediğine, araştırmanın amacına, neyin gündem olduğuna, neyin kullanışlı olacağına, neyin inanılır olacağına ve eldeki zaman ve kaynaklarla neyin yapılabileceğine bağlıdır. Bu açıdan alan yazındaki nitel çalışmaların tamamının farklı sayıda örnekler üzerinde yürütüldüğü belirlenebilir (Baltac1, 2018, s. 261).

Seçilen 16 konaklama işletmesinin üst düzey yöneticileri ile görüşülmüştür. Veriler 2018 yılının Mayıs ayında yüz yüze görüşülerek elde edilmiştir. Verilerin elde edilmesinde ses kayıt cihazı kullanılmıştır. Görüşmeler 10-40 dakika arası sürmüştür. Analizlere başlayabilmek için ilk önce ses kayıtlanı yazıya geçirilmiştir. Daha sonra elde edilen verilerin analiz edilmesinde içerik analizi tekniği kullanılmıştır.

Nitel araştırma yöntemlerinde yaygın olarak kullanılan veri analiz yöntemi içerik analizi tekniğidir. İçerik analizinin araştırmacıya birçok avantajı bulunmaktadır. Bu analiz sürecinde elde edilen bulguları düzenlemede ve yorumlamada içerik analizi kolaylık sağlamaktadır. Bununla birlikte ilk olarak yapılması gereken süreçte betimsel analiz için kavramsal çerçeve oluşturulur ve elde edilen veriler mantıklı ve anlaşılır biçimde betimlenir. Sonra yapılan bu betimlemeler analiz edilir ve yorumlanır. En son olarak neden-sonuç ilişkileri belirlenir ve yorumlama ile birlikte bazı sonuçlara ulaşılır (Sığrı, 2018, s. 308).

\section{BULGULAR}

Görüşmeye katılan üst düzey yöneticilerin araştırma konusuna dair bilgilerini göstermesi açısından tecrübe durumları aşağıdaki tabloda verilmiştir. Tablo incelendiğinde katılımcıların hepsinin hizmet sektörü olan turizmde oldukça uzun yıllar çalıştıkları ve deneyimli oldukları görülmektedir. Ayrıca genel tecrübelerinin yanı sıra Bodrum destinasyonundaki tecrübelere de bakıldığında en düşük sürenin 5 yıl olduğu, en yüksek ise 20 yıl olduğu görülmektedir. Dolayısıyla görüşme yapılan üst düzey yöneticilerin Bodrum'daki tecrübelerinin 5 ila 20 yıl arasında değiştiği söylenebilir. Tabloda dikkat çeken bir başka nokta ise görüşme yapılan üst düzey yöneticilerin bazılarının genel tecrübeleri ile Bodrum destinasyonundaki tecrübelerinin birbirine eşit olmasıdır. Buradan çıkarılabilecek sonuç, yöneticilerin iş hayatlarına Bodrum'da başladıkları ve Bodrum destinasyonunu, özelliklerini, işleyişi yapısını ve rekabet doğasını iyi bildikleri yönünde olabilir.

Tablo 2. Katılımclların Tecrübe Durumları

\begin{tabular}{|c|c|c|c|}
\hline & $\begin{array}{c}\text { Turizm Sektöründeki } \\
\text { Tecrübesi }\end{array}$ & $\begin{array}{c}\text { Bodrum Destinasyonu } \\
\text { Tecrübesi }\end{array}$ & $\begin{array}{c}\text { İşletme İçerisindeki } \\
\text { Tecrübesi }\end{array}$ \\
\hline 1. Katılımeı & $16 Y_{11}$ & $10 Y_{11}$ & 3 Yil \\
\hline 2. KatılımcI & $10 \mathrm{Y}_{11}$ & 5 Yil & 2 Y1l \\
\hline 3. Katılımci & $14 Y_{11}$ & $11 Y_{1}$ & 1 Y1l \\
\hline 4. Katılımcı & $30 \mathrm{y} 1 \mathrm{l}$ & $10 \mathrm{Y}_{11}$ & $1 \mathrm{Y}_{1}$ \\
\hline 5. KatılımeI & $15 \mathrm{Y} 1 \mathrm{l}$ & 5 Yil & 1 Yil \\
\hline 6. Katılımeı & $13 \mathrm{Y}_{11}$ & $13 Y_{11}$ & $6 Y_{11}$ \\
\hline 7. Katılımcı & $22 Y_{11}$ & 8 Yil & 3 Yil \\
\hline 8. Katılımcı & 30 Y1l & $19 Y_{11}$ & $1 \mathrm{Y}_{11}$ \\
\hline
\end{tabular}




\begin{tabular}{|c|c|c|c|}
\hline 9. Katılımcı & $32 \mathrm{Y}_{11}$ & $17 \mathrm{Y}_{11}$ & $12 Y_{11}$ \\
\hline 10. Katılımeı & 19 Y1 & 6 Y11 & 6 Ay \\
\hline 11. Katılımcı & 25 Y1l & 8 Yil & $3 Y_{11}$ \\
\hline 12. Katılımcı & 15 Y1l & 9 Yil & $8 Y_{11}$ \\
\hline 13. Katılımcı & 20 Y1 & 20 Y1l & $5 Y_{11}$ \\
\hline 14. Katılımcı & 9 Yil & 9 Yil & $2 Y_{11}$ \\
\hline 15. Katılımcı & 12 Y1 & 6 Yil & $5 Y_{11}$ \\
\hline 16. Katılımcı & $10 \mathrm{Y}_{11}$ & $10 \mathrm{Y}_{11}$ & $1 \mathrm{Y} 1 \mathrm{l}$ \\
\hline
\end{tabular}

\section{Rekabetin Genel Çerçevesine Yönelik Bulgular}

Araştırma kapsamında rekabetin genel çerçevesiyle ilgili soruya 14 katılımcı yoğun rekabet içerisinde oldukları ve rekabetten etkilendikleri yönünde görüss belirtirken, 2 katılımcı ise Bodrum genelinde rekabetin olduğunu ancak yakın çevrelerinde kendilerini etkileyen bir rekabetin olmadığını ifade etmiștir.

\section{İşletmenin Kuruluş Yeri ve Konumunun Rekabet Avantajına Etkisine Yönelik Bulgular}

Araştırmada işletmenin kuruluş yeri ve konumunun rekabet avantajına etkisini ölçmeye yönelik soruya 15 katılımcı avantaj sağladığı yönünde görüş bildirmiştir. 9 katılımcı denize sıfir konumda yer aldıklarını ve kendilerine özel sahili olduklarına vurgu yapmıştır. 6 katılımcı ise işletmenin denize sıfır konumda yer almamasının dezavantajları olduğunu ancak beraberinde başka avantajları da getirdiğini belirtmiştir. Bir katılımcı ise kuruluş yeri ve konumun rekabette avantaj sağlamadığ yönünde görüş bildirmiştir.

\section{Rakiplerden Farklı Olduğu Düşünülen Konulara Yönelik Bulgular}

Araştırmada rakiplerden farklı olduğu düşünülen konuların rekabet avantajına etkisini ölçmeye yönelik soruya katılımcılar çok farklı görüşler bildirmişlerdir. Alınan cevaplardan benzerlik gösteren bazı konular ise Bodrum merkeze yakınlık, restoran kalitesi, büyük bir firmanın bünyesinde olmak ve ultra her şey dâhil konseptinde faaliyet göstermek şeklinde öne çıkmıştır. Diğer konular ise rakiplerden farklı konsept olarak çalışmak, çocuklara yönelik aktiviteler sunabilmek, çocuk kabul etmemek, Avrupa'da en iyi otel ödülü almış olmak şeklinde sıralanabilir.

\section{Çalışanların Bilgi ve Yeteneklerinin Rekabet Üstünlü̈̆̈̈̈ne Katkısına Yönelik Bulgular}

Araştırmada çalışanların bilgi ve yeteneklerinin rekabet avantajına etkisini ölçmeye yönelik soruya katılımcıların tamamı personelin çok önemli olduğu yönünde görüş bildirmiştir. 16 katılımcıdan 15 ' $\mathrm{i}$ işletme bünyesinde uzun yıllardır çalışan personellerin olduğunu belirtmiştir. Bir katılımcı ise tüm çalışanların yeni olduğunu söylemiş, bunun sebebinin de eski çalışanların yeterli hizmet kalitesini verememesi olduğunu belirtmiştir.

\section{Tedarikçilerle Olan İlişkilerin Rekabet Üstünlü̈̆̈̈̈ne Etkisine Yönelik Bulgular}

Araştırmada tedarikçilerin rekabet avantajına etkisine yönelik soruya 12 katılımcı tedarikçileriyle ikili ilişkilerinin iyi olduğunu, bunun da rekabette avantaj sağladığını belirtmiştir. Bu katılımcıların çalıştığı işletmelerin her şey dâhil konseptinde çalışan otel işletmeleri olduğu görülmüştür. Tedarikçilerin rekabet avantajına etkisi olduğu yönünde görüş bildiren katılımcılar ikili ilişkilerini iyi tutmak için nakit ve peşin ödeme yaptıklarını, kazan-kazan mantığı ile çalıştıklarını ifade etmişlerdir. 4 katılımcı ise tedarikçilerin rekabette etkili olmadığı yönünde görüş bildirmiştir. Bu katılımcıların çalıştığı otel işletmelerinin odakahvaltı şeklinde hizmet verdikleri görülmüştür.

\section{Müşteri İstek ve Beklentilerinin Stratejiler Üzerine Etkisine Yönelik Bulgular}

Araştırmada müşteri istek ve beklentilerinin rekabet stratejisine etkisine yönelik soruya 3 katılımcı müşteri istek ve beklentilerinin izledikleri stratejiyi etkilemediği yönünde görüş bildirmiştir. 5 katıllımc1 müşteri istek ve beklentilerine göre ufak değişiklikler yaptıklarını ancak strateji değişikliğinin söz konusu olmadığını belirtmiştir. 6 katılımcı müşteri istek ve beklentilerine göre hareket ettiklerini 
belirtmiştir. 2 katılımcı müşteri istek ve beklentilerine göre tamamen strateji değişikliğine gittiklerini belirtmiştir.

\section{Müşteriler İçin Değer Oluşturmada Öncelik Verilen Konulara Yönelik Bulgular}

Araştırmada müşteriler için değer oluşturmada öncelik verilen konulara yönelik sorulara katılımcılar genel olarak fiyat, kalite ve personel olarak görüş bildirmişlerdir. Fiyat ve kaliteden söz eden katılımcılar fiyat-kalite dengesini göz önünde bulundurduklarını ifade etmişlerdir.

\section{Otellere İkame Olabilecek İşletmelerin Rekabet Duruma Etkisine Yönelik Bulgular}

Araştırmada otellere alternatif olabilecek apart, pansiyon vb. işletmelerin kârlılık ve rekabet durumuna etkisine yönelik soruya 15 katılımcı kesinlikle etkilemeyeceği yönünde görüş bildirirken 1 katılımcı ise bu küçük işletmelerin fiyatları aşağı çekmesinden dolayı kârlılığı ve rekabeti etkilediği yönünde görüş bildirmiştir.

\section{Bulunulan Pazarın Genişleme Ve Yeni Rakiplerin Dâhil Olma Durumuna Yönelik Bulgular}

Araştırmada pazarın genişleme ve yeni rakiplerin pazara dâhil olmasına yönelik soruya katılımcıların çoğunluğu pazarın genişleme ve yeni rakiplerin girme ihtimalinin olmadığı yönünde görüş bildirmiştir. Görüşmelerde 11 katılımcı pazarın genişleme durumunun olmadığını, yeni ve güçlü rakiplerin girme ihtimalinin olmadığını ifade ederken, 5 katılımcı ise yeni ve güçlü rakiplerin girdiğini, pazarın genişlediğini ifade etmiştir.

\section{Otelcilik Endüstrisinde Sürdürülebilir Rekabet Üstünlü̈̆̈̈ Elde Etmek İçin İzlenilen Stratejilere Yönelik Bulgular}

Araştırmada otelcilik endüstrisinde sürdürülebilir rekabet üstünlüğü elde etmek için izlenilen stratejilere yönelik soruya katılımcıların geneli geri bildirimlere önem vermek, müşteri memnuniyetini en iyi şekilde sağlamak, sürekli müşteri kitlesini oluşturmak şeklinde cevap vermiştir.

\section{SONUÇ}

Araştırma sonuçlarına göre otel işletmelerinin büyük bölümü bulundukları pazarda yoğun bir rekabet içerisinde olduklarını belirtmişlerdir. Bodrum pazarına büyük otellerin giriş yapması, pazarda çok sayıda otel işletmesinin faaliyet göstermesi, mevcut otellerin sürekli olarak kendini geliştirmeye devam etmesi yoğun rekabeti getiren nedenler olarak öne çıkmaktadır. Diğer yandan Bodrum'u tercih eden turist sayısının beklenilen düzeyde yükselmemesi rekabeti daha da güçlendirmektedir. Bu yoğun rekabet içerisinde her bir işletme kendi pazar payını korumaya çalışmaktadır. Rekabet içerisindeki işletmelerin büyük bir kısmı Bodrum'un genel rekabetinden çok yakın çevrelerinde yer alan rakipleri ile daha yoğun bir rekabet içinde olduklarını belirtmişlerdir. Bu rekabette her işletmenin kendi rakiplerini belirlemiş durumda olduğu ve belirledikleri bu rakipleri göz önüne alarak hareket ettiği gözlemlenmiştir. İşletmelerin rakiplerini belirlerken aynı müşteri kitlesine hitap etme, birbirlerine çok yakın konumda yer alma, aynı otel konseptinde çalışma gibi etmenlere dikkat ettikleri ortaya çıkmıştır.

Bu sonuç, Köroğlu ve diğerleri (2011) tarafından yapılan araştırmanın sonuçları ile zıtlık göstermektedir. Köroğlu ve diğerleri (2011), yaptıkları araştırmada otelcilik sektöründeki rekabetin ana sebebini otel işletmelerinin içerisinde olduğu piyasa türünün bölgesel, ülkesel veya küresel seviyede tekelci rekabet ve oligopol piyasa özelliği göstermesi şeklinde açıklamışlardır. Oysa bu araştırmada çok fazla satıcının olduğu, bunun da rekabeti daha da arttırdığı sonucuna ulaşılmıştır. Tekelci ve oligopol piyasa yerine tam rekabet piyasasının olduğu söylenebilir.

Araştırma bulgularından yola çıkılarak otel işletmelerinin bulunduğu pazara yeni ve güçlü rakiplerin girmesinin zor olduğu sonucuna ulaşılmıştır. Yeni ve güçlü rakip işletmelerin girme olasılığının olmadığı yönünde görüş bildiren katılımcıların çoğu bunun nedenini bulundukları konumda yeni tesisler için boş yerlerin olmamasına bağlamışlardır. Birkaç katılımcı pazarda iyi bir konumda oldukları için kendilerini etkileyecek rakiplerin girmesinin mümkün olmadığı yönünde görüş bildirirken birkaç katılımcı da altyap1 yetersizliklerinden dolayı yeni rakiplerin girme olasılı̆̆ının olmadığını belirtmişlerdir. Yeni rakiplerin girebildiği yönünde görüş bildiren katılımcılar da buna karş1 sürekli olarak kendilerini geliştirdiklerini ifade etmişlerdir. Bu bağlamda Porter'ın beş güç modelinde yer alan yeni giren 
firmaların tehdidi gücü maddesinin Bodrum ilçesinde faaliyet gösteren konaklama işletmelerinin izledikleri stratejiler üzerinde fazla etkisinin olmadığı söylenebilir.

Araştırmada Porter'ın beş güç modelindeki tedarikçilerin pazarlık gücü unsurunun turizm endüstrisindeki işletmelerin rekabet stratejileri üzerinde de etkisi olduğu sonucuna varılmıştır. Özellikle her şey dâhil şeklinde çalışan otel işletmeleriyle yapılan görüşmelerde katılımcılar tedarikçilerin kalitesinin otel işletmesinin hizmet kalitesini etkilediğini ifade etmişlerdir. Tedarikçilerin otel işletmelerine sunduğu hizmet ve ürün kalitesinin yüksek olmasının da rekabet avantajı sağladığını belirtmişlerdir. Tedarikçilerin rekabet avantajına etkisi olmadığı yönünde görüș bildiren katılımcıların bağlı bulundukları işletmelerin her şey dâhil şeklinde hizmet vermedikleri görülmüştür.

Araştırmada müşteri istek ve beklentilerinin izlenilen rekabet stratejisinde değişikliğe neden olabilecek kadar etkili bir unsur olduğu da görülmüştür. Katılımcılardan az bir kesimin müşteri istek ve beklentilerinin izledikleri stratejiyi değiştirecek etkide olmadığını söylemesine karşılık katılımcıların çoğunluğu müşteri istek ve beklentilerine göre hareket ettikleri yönünde görüş bildirmiştir. Katılımcıların birkaçı müşteri istek ve beklentileri karşısında büyük bir değişikliğe gittiklerini ifade etmiştir.

Katılımcıların büyük çoğunluğu kendi işletmelerine ikame olabilecek küçük konaklama işletmelerini potansiyel bir tehdit olarak görmedikleri yönünde görüş bildirmişlerdir. Otellerin alternatifi olarak görülebilecek pansiyon, apart otel vb. işletmelerin aynı pazar içerisinde bulunan ve rekabette ön sıralarda yer alan işletmeler tarafından rakip olarak görülmediği sonucuna ulaşılmıştır. Katılımcıların tamamına yakını bu tip küçük işletmelerin kendi işletmelerini olumsuz yönde herhangi bir şekilde etkilemediği ve bu tip işletmelerle aynı kategoride yer almadıkları yönünde ifade belirtmişlerdir. $\mathrm{Bu}$ tarz küçük işletmeleri tercih eden turist kitlelerinin kendi hedef kitlelerinden farklı olduklarını belirtmişlerdir. Sadece bir katılımcı bu küçük işletmelerin fiyatları aşağı çekmeleri nedeniyle kârlılıklarını etkilediklerini belirtmiştir. Bu bağlamda küçük konaklama işletmelerinin büyük otel işletmelerinin uyguladığı rekabet stratejilerini etkilemediği görülmektedir. Bu sonuç Porter'ın beş güç modelindeki ikame ürünlerin tehdidi unsurunun turizm endüstrisinde önemli olmadığını göstermektedir.

Bu açıdan, Anolay (2015) tarafından yapılan çalışmada varılan sonuçlardan biri ile bu sonucun benzerlik gösterdiği görülmektedir. Anolay (2015), oteller üzerine yaptığı araştırmada ikame ürünlerin tehdidi ile rekabet stratejileri arasında pozitif bir ilişki bulamamış ve otellere ikame olabilecek apart, pansiyon vb. işletmelerin otellerin rekabet stratejileri üzerinde dikkate alınacak bir etkisinin olmadığı sonucuna varmıştır. Bu bağlamda iki çalışma da birbirini desteklemektedir.

Görüşmeye dâhil olan katılımcıların tamamı işletme çalışanlarının bilgi ve yeteneklerinin rekabette önemli bir paya sahip olduğu yönünde görüş belirtmiştir. Rekabette ön planda olduğunu iddia eden işletmelerde çalışanların çoğunluğunun uzun yıllardır işletme bünyesinde bulundukları vurgulanmıştır. Görüşme yapılan otel işletmelerinden bir tanesinin tüm personel kadrosunun görüşme yapılan yıl içerisinde yeni baştan oluşturulduğu belirtilmiş ve bunun nedeni olarak da eski personel kadrosunun rekabette işletmeyi zor durumda bıraktıkları ve geri planda tuttukları ifade edilmiştir. Rekabet yarışı içinde belirli bir pazar payına sahip olduğunu belirterek bu yarış içinde önlerde yer aldığını söyleyen otel işletmelerinin rekabet avantajları içerisinde kaliteli personelin otel bünyesinde devamlılığının sağlanması önemli bir paya sahip olduğu görülmektedir. $\mathrm{Bu}$ da otel çalışanlarının rekabet anlamında en önemli etmenlerden biri olduğunun kanıtı niteliğindedir.

$\mathrm{Bu}$ sonuç Tüfekçiyaşar (2019) ve Akdemir (2018) tarafindan yapılan araştırmaların sonuçlarını desteklemektedir. Tüfekçiyaşar (2019), İstanbul'daki 5 yıldızlı oteller üzerine yaptığı araştırmada insan unsurunun konaklama işletmelerinde öneminin yüksek olduğuna vurgu yapmış ve kaliteli personelin misafir memnuniyetini arttırarak işletmeye rekabet avantajı sağladığını belirtmiştir. Akdemir (2018) de Muğla ilinde yapmış olduğu araştırmada nitelikli iş gücünün müşteri memnuniyeti ve hizmet kalitesini arttırdığını, dolayısıyla işletmenin rekabet üstünlüğünü etkilediğini belirtmiştir.

Görüşme yapılan katılımcıların büyük bir kesimi müşterileri açısından bir fiyat-kalite dengesi sağlamaya çalıştıkları yönünde görüş belirtmiştir. Müşterilerinden aldıkları fiyatın daha üzerinde bir hizmet vermeye çalıştıklarını belirten katılımcıların çoğunluğu fiyatlandırma konusunda da rakiplerini temel aldıklarını ifade etmişlerdir. Katılımcılar rakiplerine kıyasla daha kaliteli bir hizmet vermeye çalışıklarını belirtmişlerdir. 
Görüşmeye dâhil olan katılımcılar rekabet içinde bulundukları konumları korumak adına yoğun çaba harcadıklarını belirtmişlerdir. Bu konuda üzerinde durulan en önemli husus müşteri geri bildirimleri olarak ön plana çıkmıştır. Katılımcıların büyük çoğunluğu müşteri geri bildirim sisteminin sonuçlarına göre hareket ettiğini belirtmiş ve strateji belirlerken ilk olarak bu geri bildirimlerin göz önüne alındığını vurgulamıştır. Sürdürülebilir rekabet üstünlüğü elde etmek için kullanılan yöntemlerden bir diğer önemli olanı da her otelin kendi sadık müşteri kitlesi üzerine yaptıkları çalışmalardır. Bu doğrultuda katılımcılar ilk olarak kendi müşteri kitlelerini elde tutmaya çalıştıklarını hemen arkasından da yeni kitleler bulmaya çalıştıklarını belirtmişlerdir.

Araştırmanın bazı sonuçları Samur'un (2009) müşteri ilişkileri yönetiminin rekabet üstünlüğüne etkisini araştıran çalışması ile uyum göstermektedir. Samur (2009), Nevşehir otelleri üzerine yaptığı çalışmasında rekabetçi ortamda müşteri isteklerinin göz ardı edilemeyeceğini belirtmiştir. Bununla birlikte Samur (2019), müşteri ilişkilerinin rekabet üstünlüğü açısından önemli olduğunu gözlemlemiş ve müşteri sadakati oluşturmanın rekabet yarışında ayakta kalabilmenin temel şartlarından biri olduğunu belirtmiştir. $\mathrm{Bu}$ çalışmada da otel işletmelerinin büyük kısmının müşteri istek ve beklentileri doğrultusunda hareket ettikleri tespit edilmiştir. Ayrıca, işletmelerin rekabette öne geçmek adına sadık müşteri kitlelerini oluşturmaya çalıştıkları ve bu kitlenin memnuniyetini en üst düzeyde tutmaya çalıştıkları görülmüş̧ür.

Diğer yandan çalışmadaki bulgulardan yola çıkılarak varılan bazı sonuçlar Kılıç ve Uslu (2019) tarafindan yapılan çalışmanın bazı sonuçları ile farklılık göstermektedir. Kılıç ve Usta (2019), İstanbul'daki otel işletmelerine yönelik yaptıkları çalışmada işletmelerin farklılaşmaya odaklanmaları gerektiği ve maliyet liderliği elde ederek rekabeti sürdürebilmelerinin mümkün olduğu sonucuna varmışlardır. Oysa bu çalışmada otel işletmelerinin kaliteye önem vererek ve müşteri odaklı faaliyet yürüterek rekabet üstünlüğü elde etmeye çalıştıkları sonucuna ulaşılmıştır. Bu farklılığın, iki çalışmanın farklı turizm destinasyonları üzerine yapılmış olmalarından kaynaklandığı söylenebilir. İstanbul ve Bodrum'un farklı turizm pazarları olması, faaliyet gösteren konaklama işletmelerinin farklılıklar göstermesi ve bu iki turizm bölgesini tercih eden turistlerin ve isteklerinin farkl1l1klar göstermesi iki çalışmanın sonuçlarının farklı olmasına yol açmış olabilir.

$\mathrm{Bu}$ çalışma konaklama işletmeleri arasındaki rekabetin avantajlarını belirlemeye yönelik olarak Bodrum ilçesinde yapılmıştır. İleride yapılacak rekabet avantajı kaynaklarının belirlenmesine yönelik çalışmalara yol gösterebilir. Bodrum'daki 5 yıldızlı oteller yerine daha küçük otel işletmelerine yönelik araştırmalar yapılabilir. Rekabetin zayıf yönlerinin belirlenmesine yönelik araştırmalar yapılabilir. Bodrum dışında Türkiye'nin önde gelen diğer turizm bölgeleri seçilerek araştırmanın evren ve örneklemi değiştirilebilir.

Rekabetin gün geçtikçe arttığı turizm sektöründe rekabette önlerde yer almak isteyen konaklama işletmelerinin dikkate alması gereken konuların en başında müşteri memnuniyeti gelmektedir. Rakiplerine kıyasla avantajlı konuma geçmek isteyen işletmeler ilk önce kendi konumlarını korumaya çalışmalı daha sonrasında rakiplerinden sıyrılarak öne geçmeye çalışmalıdır. Bu doğrultuda uygulanması gereken en önemli konulardan biri de müşteri istek ve beklentilerini en iyi şekilde belirleyebilmektir. Bu da müşteri geri bildirimlerini doğru şekilde takip etmekten ve kayıt altına alabilmekten geçmektedir. $\mathrm{Bu}$ doğrultuda her konaklama işletmesinin mutlaka kendi geri bildirim sistemini oluşturması gerekmektedir. Bunu doğru biçimde yapan işletmelerin rekabet içerisinde rakiplerine göre avantajlı konumda bulundukları gözlemlenmiştir.

İşletmelerin rekabet yarışı içerisinde devam etmeleri için dikkat etmeleri gereken bir diğer nokta da kaliteli personel temini ve bu kaliteli personelin işletme bünyesinde devamının sağlanmasıdır. Hizmet sektöründe ürünü müşteriye çalışanların sunuyor olması, üretim ve tüketimin eş zamanlı olması personel kalitesinin önemini arttırmaktadır. Otel çalışanlarının güler yüzlü hizmet vermesi, otele gelen müşteriyi tanıyor olması ve tanımasının verdiği avantaj ile müşteri isteklerini önceden tahmin edebilmesi, bu isteklere hızlı bir şekilde cevap verebilmesi otel işletmesinin hizmet kalitesini arttıracaktır. Bu bağlamda maliyetleri düşürmek adına ucuz iş gücüne yönelmek yerine turizm alanında eğitim görmüş ve bu sektör içerisinde belirli bir altyapısı olan personeli işletme bünyesine dâhil etmek akıllıca bir seçim olacaktır. Kaliteli personeli işletmeye kazandırmak da yeterli değildir. Bu kaliteli personelin işletme içerisinde devamlılığının sağlanması da hizmet kalitesinin sürekliliği açısından önemlidir. 
Araştırma, Bodrum ilçesinde yer alan ve görüşmeyi kabul eden konaklama işletmeleri yöneticileri ile sınırlıdır. Bodrum ilçesinde çok fazla konaklama işletmesinin yer alması ve araştırmanın saha çalışması kısmında tüm konaklama işletmeleri ile görüşme yapmanın neredeyse imkânsız olması araştırmanın sınırılığını oluşturmaktadır. Araştırmada kullanılan girdiler literatür taraması ve görüşme tekniği ile elde edilen katılımcı görüşleriyle sınırlı kalmaktadır. Araştırma sonuçları Bodrum destinasyonundaki konaklama işletmelerinden toplanan verilerden yola çıkılarak elde edilmiştir. Farklı turizm destinasyonlarında bu araştırma sonuçları ile benzerlik göstermeyen sonuçlar elde edilebilir.

Bilgilendirme / Acknowledgement: Bu makale Hakan Çakırlı’nın Dr. Öğr. Üyesi Yıldırım Yıldırım danışmanlığında hazırladığı aynı adlı yüksek lisans tezinden yararlanılarak oluşturulmuştur.

\section{KAYNAKÇA}

Akdemir, R. (2018). Yeşil pazarlama stratejilerinin rekabet avantajına etkisinin incelenmesi: Muğla ilinde yer alan 4 ve 5 yıldızlı otel işletmelerine yönelik bir araştırma. Yayımlanmamış yüksek lisans tezi, Sttkı Koçman Üniversitesi Sosyal Bilimler Enstitüsü, Muğla.

Akgöz, E. (2013). Düşünceden uygulamaya otel işletmeciliği. Ankara: Gazi Kitabevi.

Aktan, C. C. ve Vural, İ. Y. (2004). Rekabet gücü ve rekabet stratejileri. Ankara: TíSK Yayınları.

Anolay, R. M. (2015). Algılanan rekabet güçleri, rekabet stratejisi ve organizasyonel performans ilişkisi: Türkiye otelcilik endüstrisi. Yayımlanmamış yüksek lisans tezi, İstanbul Teknik Üniversitesi Fen Bilimleri Enstitüsü, İstanbul.

Aslan, A. (2008). Turizm planlamasına yerel toplumun katılımı: Saklı Bahçe Akyaka üzerine bir inceleme. Anatolia: Turizm Araştırmaları Dergisi, 19(1), 71-83.

Baltac1, A. (2018). Nitel araştırmalarda örnekleme yöntemleri ve örnek hacmi sorunsalı üzerine kavramsal bir inceleme. Bitlis Eren Üniversitesi Sosyal Bilimler Enstitüsü Dergisi, 7(1), ss.231274

Çavuş, Ş. ve Öncüer, M. (2009). Türkiye’de konaklama sektörünün gelişimi. (Ed. Ş. Çavuş, Z. Ege ve O. E. Çolakoğlu). Ankara: Detay Yayıncılık.

Dinçer, Ö. (1998). Stratejik yönetim ve işletme politikası. İstanbul: Beta Yayınları.

Erdem, B. (2002). Otel işletmelerinde insan kaynakları yönetimi açısından personel bulma ve seçme süreci: Örnek bir uygulama. Yayımlanmamış yüksek lisans tezi, Balıkesir Üniversitesi Sosyal Bilimler Enstitüsü, Balıkesir.

Eren, E. (2013). Stratejik yönetim ve işletme politikası. İstanbul: Beta Yayınc1lık.

Eser, Z. (2007). Hizmetlerde pazarlama iletişimi. Ankara: Siyasal Kitapevi

Glaser, B. G. ve Strauss, A. L. (1967). The discovery of grounded theory: Strategies for qualitative research. New York, NY: Aldine De Gruyter.

Hatiboğlu, Z. (1995). Işsletmelerde stratejik yönetim. İstanbul: Sedok Yayınları.

İslamoğlu, A. H., Candan, B., Haciefendioğlu, Ş. ve Aydın, K. (2006). Hizmet pazarlaması. İstanbul: Beta Yayınları

Karluk, R. (1996). Türkiye ekonomisi: Tarihsel gelişim, yapısal ve sosyal değişim. İstanbul: Beta Yayınları.

Kavrakoğlu, İ., Gedik, S. ve Balkır, M. (2002). Yeni rekabet stratejileri ve Türk sanayisi. İstanbul: Lebib Yalkın Yayınları.

Kılıç, B. ve Uslu, T. (2019). Porter'ın rekabet modelinin İstanbul'daki zincir otel işletmelerinde incelenmesi. Uluslararası Global Turizm Araştırmaları Dergisi, 3(2), 83-98. 
Kırım, A. (1998). Yeni dünyada strateji ve yönetim, İstanbul: Sistem Yayıncılık.

Köroğlu, Ç., Biçici F. ve Sezer D. (2011). Otel işletmelerinde maliyet kontrolünün rekabet üstünlügüne etkisi. İsletme Araştırmaları Dergisi, 3(1), 33-48.

Lindof, T. R. ve Taylor, B. C. (2011). Qualitative communication research methods (3rd ed.). USA: Sage Pub.

Mohelska, H. ve Sokolova, M. (2018). Management approaches for industry 4.0: The organizational culture perspective. Technological and Economic Development of Economy, 24(6), 2225-2240.

Özdemir, M. ve Kervankıran, İ. (2011). Turizm ve turizmin etkileri konusunda yerel halkın yaklaşımlarının belirlenmesi: Afyonkarahisar örneği. Marmara Coğrafya Dergisi, 24, 1-25.

Özel, Ç. H. (2012). Otel işletmelerinde yiyecek içecek hizmetleri yönetimi. (Ed. K. M. Akoğlan.) Ankara: Detay Yayincilik.

Özkan, R. B. (2007). Rekabet stratejileri ve örnek bir sektör analizi. Yayımlanmamış yüksek lisans tezi, Marmara Üniversitesi Sosyal Bilimler Enstitüsü, İstanbul.

Patton, M. Q. (1990). Qualitative research evaluation methods. Newbury Park: California.

Pearce II, J. ve Robinson, R. B. (2015). Stratejik yönetim. (Çev. M. Barca.) Ankara: Nobel Akademik Yayıncilik.

Porter, M. E. (2000). Rekabet stratejisi: Sektör ve rakip analizi teknikleri. İstanbul: Sistem Yayınc1lık.

Porter, M. E. (2010). Rekabet üzerine. (Çev. K. Tanrıyar.). İstanbul: Optimist Yayınları.

Resmi Gazete, (2000). Turizm tesisleri yönetmeliği. VII. Beş yıllık Kalkınma Planı, Özel İhtisas Raporu, Ankara, Say1:24101.

Roney, SA. (2011). Turizm bir sistemin analizi. Ankara: Detay Yayınc1lı.

Samur, A. N. (2009). Müssteri ilişkileri yönetimi uygulamaları rekabet üstünlüğ̈̈ arasındaki ilişkinin belirlenmesi: Nevşehir otelleri üzerine bir uygulama. Yayımlanmamış yüksek lisans tezi, Niğde Üniversitesi Sosyal Bilimler Enstitüsü, Niğde.

Sığrı, Ü. (2018). Nitel araştırma yöntemleri. İstanbul: Beta Yayıncılık.

Topçuoğlu, M. (2001). Rekabeti kısıtlayan teşebbüsler arası işbirliği davranışları ve hukuki sonuçları. Ankara: Rekabet Kurumu Yayını.

Tüfekçiyaşar, T. (2019). Konaklama işletmelerinde sürdürülebilir rekabet üstünlügüüü etkileyen faktörler: Istanbul'daki 5 yıldızlı otellerin nitelikli iş gücü açısından değerlendirilmesi. Yayımlanmamış yüksek lisans tezi, İstanbul Üniversitesi Sosyal Bilimler Enstitüsü, İstanbul.

Valenti, C. ve Riviere, J. (2008). The concept of sensory marketing. Marketing dissertation. 1 Haziran 2019

https://stosowana.files.wordpress.com/2010/12/the concept of sensory marketing.pdf

tarihinde adresinden erişildi.

4054 sayıl rekabetin korunması hakkında kanun. R.G. Tarihi: 13.12.1994, R.G. Sayıs1: 22140. 1 Haziran 2019 tarihinde http://www.rekabet.gov.tr/tr-TR/Sayfalar/4054-Sayili-Kanun adresinden erişildi. 